Article

\title{
R\&D Accounting Treatment, R\&D State and Tax Avoidance: With a Focus on Biotech Firms
}

\author{
Namryoung Lee \\ School of Business, Korea Aerospace University, Goyang 10540, Korea; nrlee@kau.ac.kr
}

Received: 25 November 2018; Accepted: 20 December 2018; Published: 21 December 2018

\begin{abstract}
This study examines the correlation among R\&D accounting treatment, R\&D state and tax avoidance behavior, with a focus on biotech firms. Findings from the analysis show that most firms are unlikely to capitalize R\&D in a steady state; however, in the case of biotech firms, this is not the case. This may be due to biotech firms' accounting choice to capitalize R\&D outlays based on a strong belief in future opportunities of commercial success. Moreover, the analysis of tax avoidance behavior finds that firms with low capitalization in an R\&D steady state have a positive correlation with tax avoidance, whereas biotech firms do not. The results imply that biotech firms focus on sustainable commercial success unlike the general patterns of other industries.
\end{abstract}

Keywords: R\&D accounting treatment; R\&D stage; tax avoidance; biotech sustainability

\section{Introduction}

In 2018, the most popular stocks on the Korean stock market were biotech stocks. Eight out of ten of the fastest-growing stocks were biotech. According to the Korea Exchange, eight out of the top ten market capitalization companies in the KOSDAQ market were also bio-related. It is the first time that eight out of ten companies in the KOSDAQ market have been bio companies. In 2018, large orders of over 100 million won have increased significantly, in particular, focusing on investing in bio stocks.

Despite many biotech firms recording losses, their market value seems to continue to rise due to the anticipation of future firm value through the commercial success of research and development (hereafter, R\&D). Given their nature, biotech firms require a massive amount of investment in R\&D. This is a part of the effort to maintain sustainability in the highly competitive market. It costs an average of $\$ 800$ million to develop one product [1], and sustained R\&D spending is essential. In particular, the controversial issue related to biotech firms concerns the accounting treatment of R\&D spending. In Korea, R\&D capitalization is allowed in cases where the conditions set forth by the K IFRS (Korean International Financial Reporting Standards) are met. However, the problem is the discretionary behavior in applying R\&D accounting standards. While the capitalized R\&D assets ratio to total assets of all Korean listed companies is $1 \%$, that ratio in the biotech industry (to both biopharma firms and biotechnology firms) amounts to 4\%. According to the Korean FSS (Financial Supervisory Service), as of the end of $2016,55 \%$ of the biopharma companies, or 83 firms are treating R\&D investments as assets rather than expenses. In biotech, where R\&D spending is significantly higher than in other industries, it is deemed that R\&D capitalization is maximized to boost corporate profit and value in the early stages, based on the optimistic expectations of success in R\&D.

While various motivations may drive firms $R \& D$ capitalization, many prior studies have proved that $R \& D$ capitalization is mostly motivated by earnings management purposes [2-4]. In addition, various financial factors including leverage, total $R \& D$ spending and profitability have been found to affect firms' R\&D accounting treatment. When a firm's life cycle is taken into account, some studies have proven that firms in a mature stage or steady stage in their R\&D program are less likely to capitalize [5]. 
According to the global 100 ranking, an annual list of the world's most sustainable companies from Corporate Knights (A magazine, research, and financial information products company), based on 14 key measures, German industrial giant Siemens was rated as the most sustainable company in 2017. Corporate sustainability appears to be vital for a successful future. R\&D spending seems to be a key indicator of how innovative an industry is, and vital for a sustainable future. Focusing on this trend, this study examines the correlation between the stage of the firm's R\&D program and the accounting treatment of $R \& D$. It is expected that the $R \& D$ capitalization would be eased in an R\&D steady state, as proven in previous studies. On the other hand, biotech firms are expected to show a different tendency as R\&D spending is significantly higher than in other industries and it is considered more important, particularly for sustainable commercial success.

While firms pay attention to tax payments as well as revenue generation, most firms also take an interest in both earnings management and tax avoidance. The strategy to reduce tax burden is one of the most important aspects of financial planning. Intuitively, with respect to R\&D accounting treatment, expensing rather than capitalization is more associated with tax aggressiveness behavior. As discussed in prior studies, R\&D accounting treatment can impact tax payments [6-8]. Overesch and Wamser [9] show that R\&D activities are very tax-sensitive. In particular, for high-tech firms, $R \& D$ is used as a proxy for profit shifting opportunities. Overesch and Schreiber [10] find that $R \& D$ intensive multinationals can shift firms' taxable profits to low tax countries, this scheme can be done through intercompany transactions. Profit shifting of multinational corporations (MNCs) has been discussed in many research papers [11-14]. Pharmaceutical firms, in particular, derive most of their profits from their intellectual properties. This gives an opportunity for profit shifting from the high tax host country to low tax countries [15].

Therefore, this study also examines if firms in an R\&D steady state with a low tendency of R\&D capitalization engage in tax avoidance activities. In the case of biotech firms, it is also expected that typical tax aggressiveness using $R \& D$ will not be seen.

The remainder of the paper is organized as follows: Chapter 2 provides a literature review and hypotheses. Chapter 3 discusses research samples and methodology. Chapter 4 presents descriptive statistics, correlations, and regression results. Chapter 5 discusses the results and suggests points based on the analysis.

\section{Literature Review and Hypotheses}

R\&D investment has been found to have a positive impact on firms' performance [16-19]. Xu and Sim (2018) find the positive relationship between R\&D intensity and firm performance in emerging markets. Lev and Sougiannis (1996) show that R\&D investment is associated with an earnings increase. Reynard (1979) proved that R\&D investment cuts bring about a decline in profit.

However, as R\&D investment causes cash outflows, it is aimed at long-term value enhancement and sustainability, not for short-term profit. However, for the firms with low performance, discretionary $R \& D$ capitalization can be used for opportunistic earnings management $[2-4,20,21]$. A high level of $R \& D$ expenditure in a firm is positively associated with $R \& D$ capitalization as consistently proved in previous studies [5,20,22-25].

Financial factors such as the firm's size, debt ratio, and profitability also affect R\&D accounting treatment, though previous studies have produced mixed results. As shown in the following research papers, such financial factors have been proven to have either a positive or a negative association with R\&D capitalization. Daley and Vigeland [26] find that firms with a higher debt ratio are more likely to capitalize and large-sized firms are more likely to expense R\&D outlays. Aboody and Lev [20] find that a firms' size and profitability are positively related to R\&D capitalization, while software development intensity and debt ratio have a significant negative correlation with R\&D capitalization. Oswald [5] re-examines Aboody and Lev's [20] examination and finds that larger firms tend to expense their R\&D spending and steady-state firms are more likely to expense their R\&D outlays. Oswald [5] defines a steady state with respect to a firm's R\&D intensity as the state where the R\&D capitalization amount 
equals the amortization amount. Seemingly, firms aim to maintain the current capitalized R\&D level rather than attempt to capitalize further on R\&D.

By extending the existing literature regarding $R \& D$ accounting treatment, this study seeks to relate $R \& D$ accounting treatment with the stage of a firm's $R \& D$ program and compare this with the tendency of biotech firms. As proven by Oswald [5], firms in the steady state may be less likely to capitalize, but in the case of biotech firms that spend a lot more on R\&D, a different tendency was observed. As a result, biotech firms are predicted to have a strong tendency to capitalize R\&D expenditures even in the mature stages of R\&D. If so, it implies that firms continuously focus on revenue generation, increasing profit, and market value enhancement through the success of research and development projects. Therefore, this study sets the following Hypothesis 1.

H1. Firms in the R\&D mature stage will be less likely to capitalize their R\&D spending, but this will not be the case for biotech firms.

Meanwhile, expensing of R\&D spending is immediately tax-deductible. Stickney and McGee [27] verify that $R \& D$ intensive firms strategically use tax-deductible $R \& D$ expenditures for tax aggressiveness. In addition, a positive association between R\&D expensing and tax aggressiveness has also been verified [6-8].

Gupta and Newberry [7] find R\&D expenses have a significant negative association with CETRs (Cash Effective Tax Rates), in pre-Tax Reform Act 1986. Richardson and Lanis [8] also find that firms with a higher R\&D intensity (R\&D expenditures divided by sales) have lower ETRs (Effective Tax Rates). Belz et al. [28] examine the effect of R\&D intensity on Effective Tax Rate using meta-regression techniques and found that the R\&D tax accounting and R\&D profit shifting affect ETR is at the ratio of 2:1. This implies that one-third of the R\&D effect on the ETR is caused by the tax accounting effect.

The second hypothesis expands the first hypothesis and analyzes the correlation between firms with low R\&D capitalization that are in an R\&D steady stage, and their tax aggressiveness. The tendencies of biotech firms are similarly compared. For the firms with a tendency of low R\&D capitalization and in an R\&D steady stage, there is a likelihood of expensing R\&D outlays. Therefore, they are expected to engage in tax aggressive activities. However, if biotech firms do not show the same tendency to capitalize even in the mature stage, it is not expected that biotech firms will show tax aggressive behaviors, and therefore this study sets Hypothesis 2 as follows:

H2. If a firm is in an R\&D steady stage and has a lower tendency to capitalize R\&D, it will engage in tax avoidance activities. However, this will not be the case for biotech firms.

\section{Research Design}

\subsection{Sample Selection}

This study employs financial data made available by KIS-DATA, a database developed by Korea Investors Service, Inc., for 2000 to 2017. The sample includes publicly traded nonfinancial firms on the Korean Stock Exchange (KSE, KOSPI: The Korea Composite Stock Price Index or KOSPI is the index of all common stocks traded on the Stock Market Division-previously, Korea Stock Exchange-of the Korea Exchange. It is the representative stock market index of South Korea, like the Dow Jones Industrial Average or S\&P 500 in the United States) that have a fiscal year-end of December 31, and have unimpaired capital. The top and bottom $1 \%$ of all continuous variables are winsorized to moderate the influence of outliers. Thus, the final sample includes 26,334 firm-year observations. Of the sample firms, $6.16 \%$ are biopharma or biotech firms. Table 1 shows the industry distribution of the sample. 
Table 1. Industry Distribution of the sample.

\begin{tabular}{ccc}
\hline Industry & Number of Firms & $\%$ \\
\hline Agriculture/Forestry/Mining/Fishing & 120 & 0.46 \\
Manufacturing & 15,763 & 59.86 \\
Electricity/Water Supply/Environment & 256 & 0.97 \\
Construction & 922 & 3.50 \\
Wholesale/Retail & 1932 & 7.34 \\
Transportation/Warehousing & 440 & 1.67 \\
Lodging/Restaurants & 28 & 0.11 \\
Publication/Broadcasting/Communication & 1892 & 7.18 \\
Medical/Computer/Information & 825 & 3.13 \\
Real Estate/Renting/Leasing & 66 & 0.25 \\
Biopharma/Biotech & 1623 & 6.16 \\
Others & 2467 & 9.37 \\
\hline Total & 26,334 & 100 \\
\hline
\end{tabular}

\subsection{Regression Model and Measurement of Variables}

To examine Hypothesis 1, the following logit regression model is used.

$$
\mathrm{LCAP}_{i, t}=\alpha+\beta_{1} \text { Mature }_{i . t}+\beta_{2} \text { MatureBio }_{i . t}+\sum \alpha_{j} \mathrm{X}_{j}+\sum \alpha_{k} \mathrm{IND}_{k}+\sum \alpha_{l} \mathrm{YEAR}_{l}+\varepsilon_{i, t}
$$

where $\operatorname{LCAP}_{i, t}$ is a dummy variable equal to 1 if the capitalized R\&D divided by total assets is less than the median. Otherwise, it is coded as 0 . For logit regression, continuous variables are categorized-splitting the sample into two categories-by the "LCAP" values below the median. Though the categorization may be arbitrary, this study focuses on meaningful qualitative differences between the groups rather than analyzing the linear relationship between a steady state, with respect to $R \& D$, and the capitalized R\&D amount.

Mature $_{i . t}$ is defined as the steady state of a firm's R\&D intensity, following Oswald's [5] classification. The steady state is defined as the state where the amount of capitalized R\&D is similar in magnitude to the amount of amortization. Alternatively, firms in a steady state are defined as firms that capitalize R\&D spending only to maintain the current capitalized R\&D level. Therefore, Mature $_{i . t}$ is coded as 1 if the difference between the amount of capitalized R\&D and the amount amortized is less than the median, and as 0 otherwise. An alternative measurement for the mature stage may be used. Mature $e_{i . t}$ is coded as 1 if the change in capitalized R\&D outflow is less than the median, and as 0 otherwise. MatureBio ${ }_{i . t}$ is the mature dummy variable for biotech firms. Therefore, MatureBio $i . t$ coded as 1 represents biotech firms in the steady state. $X_{i . t}$ is the other factor affecting R\&D accounting treatment (explained below), IND is the industry indicator variables, and YEAR is the year indicator variable.

The model includes control variables that can affect $R \& D$ accounting treatment. These variables include size, leverage, return on assets, $R \& D$ program, and sales growth. Size, which is measured as the natural $\log$ of total assets, is included to control for size effects. Size may have a positive association with R\&D capitalization [20], or negative association with R\&D capitalization [5]. Leverage is the total liabilities divided by total assets and shows mixed results. Leverage may have a positive association with R\&D capitalization [26] or a negative association with R\&D capitalization [20]. Return on assets, which is measured as net income divided by total assets, is included to control for firm profitability [20]. R\&D program firms with greater R\&D intensity may be more likely to capitalize R\&D spending [5,20,22-25].

Sales growth is included to control for growth. Finally, industry dummy variables, defined by the one-digit Korea Standard Industry Code, and year dummy variables are included as control variables. 
The regression model for the analysis of Hypothesis 2 is as follows.

$$
\text { TAvoid }_{i, t}=\alpha+\beta_{1} \text { LCAPmature }_{i . t}+\beta_{2} \text { LCAPmatureBio }_{i . t}+\sum \alpha_{j} \mathrm{X}_{j}+\sum \alpha_{k} \mathrm{IND}_{k}+\sum \alpha_{l} \mathrm{YEAR}_{l}+\varepsilon_{i, t}
$$

where TAvoid ${ }_{i, t}$ is tax avoidance, LCAPmature is the mature LCAP dummy variable, and LCAPmaturebio is the mature biotech LCAP dummy variable. $X_{i . t}$ is the other factor affecting tax avoidance (explained below), IND is the industry indicator variable, and YEAR is the year indicator variable.

To measure tax avoidance, book-tax difference (hereafter, BTD) which is the difference between taxable income and financial accounting income, is computed. BTD is frequently used to proxy tax avoidance or tax aggressiveness [29-33]. This study employs the accruals-adjusted book-tax difference measure following the method developed by Desai and Dharmapala (2006). In the following equation, the OLS regression model is performed and the residual BTD is determined.

$$
\mathrm{BTD}_{i, t}=\beta_{1} \mathrm{TA}_{i, t}+\epsilon_{i, t}
$$

where TA is the total accruals calculated by subtracting operating cash flows from net income using the measure of total accruals developed by Hribar and Collins [34], thereafter divided by the beginning of year assets.

The BTD is computed as

$$
\mathrm{BTD}_{i, t}=\mathrm{AI}-\mathrm{TI}
$$

where $\mathrm{AI}$ is the accounting income before tax and $\mathrm{TI}$ is the taxable income, which is calculated as Income Tax Expense $+\left\{\left(\right.\right.$ Deferred Tax Assets $s_{t}-$ Deferred Tax Assets $\left._{t-1}\right)-\left(\right.$ Deferred Tax Liabilities $_{t}-$ Deferred Tax Liabilities $\left.\mathrm{t}_{\mathrm{t}-1}\right)$. Thereafter, it is divided by the tax rate.

LCAPmature coded as 1 represents firms in a steady state, with respect to R\&D spending, that tend to capitalize R\&D below the sample median. LCAPmatureBio ${ }_{i . t}$ coded as 1 also represents biotech firms in a steady state, with respect to $R \& D$ spending, that tend to capitalize R\&D below the sample median. The model includes control variables that can affect tax avoidance. These variables include size, leverage, return on assets, operating cash flow, sales growth, deferred tax, and investment. Size is included to control for size effects. Size may have a positive association based on political cost theory [35] or negative association based on political power theory [36]. Debts occur tax-deductible interest payments; therefore, leverage may have a positive association with tax avoidance. Return on assets is for controlling firm profitability and may have a positive association with tax avoidance [7]. Operating cash flow is included as tax payments are a significant cash outflow. Sales growth is included to control for growth. Growing firms are more likely to buy tax-favored assets [37]. Deferred tax is included to control for future variable tax expenses. Investment is included as a firm's investment decisions may influence tax planning. Finally, industry dummy variables, defined by the one-digit Korea Standard Industry Code, and year dummy variables are included as control variables.

\section{Empirical Results}

\subsection{Descriptive Statistics}

Table 2 shows the descriptive statistics for the main variables. The mean (median) values for LCAP, Mature, Maturebio, LCAPmature, and LCAPmaturebio are 0.5454 (1), 0.6741 (1), 0.0314 (0), $0.4315(0)$, and $0.0173(0)$, respectively. The descriptive statistics for those variables mean that $54 \%(3 \%$ of biotech firms) of the sample firms had below the median R\&D capitalization and $67 \%$ ( $3 \%$ of biotech firms) of the sample firms are in mature stage with regards to R\&D. The mean (median) for TAvoid (book-tax difference) is 0.0221 (0.0419). The mean (median) for R\&D program is $0.0675(0.0632)$.

The mean (median) values for control variables SIZE, LEV, ROA, GROW, OCF, DT, and INV, are 18.5766 (18.3658), $0.4183(0.4177), 0.0312(0.0373), 0.3843(-0.0204), 0.0553(0.0518), 0.0071(0)$, and $0.2507(0.1327)$, respectively. 
Table 2. Descriptive Statistics.

\begin{tabular}{cccccc}
\hline Variables & Mean & StdDev & Median & Q1 & Q3 \\
\hline LCAP & 0.5454 & 0.4979 & 1 & 0 & 1 \\
Mature & 0.6741 & 0.4687 & 1 & 0 & 1 \\
Maturebio & 0.0314 & 0.1745 & 0 & 0 & 0 \\
LCAPmature & 0.4315 & 0.4953 & 0 & 0 & 1 \\
LCAPmaturebio & 0.0173 & 0.1304 & 0 & 0 & 0 \\
TAvoid & 0.0221 & 0.1646 & 0.0419 & 0.0164 & 0.0713 \\
SIZE & 18.5766 & 1.4927 & 18.3658 & 17.5781 & 19.3397 \\
LEV & 0.4183 & 0.2052 & 0.4177 & 0.2549 & 0.5692 \\
ROA & 0.0312 & 0.2206 & 0.0373 & 0.0053 & 0.0801 \\
RED program & 0.0675 & 2.5487 & 0.0032 & 0.0001 & 0.0192 \\
GROW & 0.3843 & 2.2159 & -0.0204 & -0.1752 & 0.0740 \\
OCF & 0.0553 & 0.1006 & 0.0518 & 0.0008 & 0.1092 \\
DT & 0.0071 & 0.0142 & 0 & 0 & 0.0081 \\
INV & 0.2507 & 0.4948 & 0.1327 & 0.0551 & 0.2535 \\
\hline
\end{tabular}

Notes. LCAP: dummy variable equals 1 if capitalized R\&D divided by total assets is less than the median, 0 otherwise. Mature: coded as 1 if the difference between the amount capitalized R\&D and the amount amortized is less than the median, 0 otherwise. MatureBio: dummy variable for a mature biotech firm. LCAPMature: mature LCAP dummy variable. LCAPMatureBio: mature biotech LCAP dummy variable. TAvoid: book-tax gap residual calculated using the method developed by Desai and Dharmapala (2006). SIZE: natural logarithm of total assets. LEV: total liabilities divided by total assets. ROA: net income divided by total assets. RED program: R\&D spending divided by total assets. GROW: sales growth. OCF: operating cash flow divided by total assets. DT: deferred taxes divided by total assets. INV: plant, property, and equipment (except land and construction in progress) divided by total assets.

The Pearson correlation results are reported in Table 3. Significant correlations are observed between tax avoidance (TAvoid, book-tax difference) and some of the explanatory variables (LCAP, Maturebio, LCAPmature, LCAPmaturebio) $(p<0.01)$. Significant positive correlations are also seen between tax avoidance and some of the control variables (ROA, OCF) $(p<0.01)$. Significant negative correlations are observed between tax avoidance and some of the explanatory variables (LEV, GROW, DT, INV) $(p<0.01)$. To test for multi-collinearity, the variance inflation factors (VIFs) are computed. No multi-collinearity problems are evident. 
Table 3. Correlations.

\begin{tabular}{|c|c|c|c|c|c|c|c|c|c|c|c|c|c|c|c|}
\hline Variable & TAvoid & LCAP & LCAPbio & mature & Maturebio & LCAPmature & LCAPmaturebio & SIZE & LEV & $R O A$ & RED program & GROW & $O C F$ & $D T$ & $I N V$ \\
\hline TAvoid & 1.0000 & & & & & & & & & & & & & & \\
\hline LCAP1 & $\begin{array}{l}0.0753 \\
0.0000\end{array}$ & 1.0000 & & & & & & & & & & & & & \\
\hline LCAPbio & $\begin{array}{c}-0.0103 \\
0.0938\end{array}$ & $\begin{array}{l}0.1613 \\
0.0000\end{array}$ & 1.0000 & & & & & & & & & & & & \\
\hline \multirow[b]{2}{*}{ mature } & 0.0052 & 0.2737 & -0.0387 & & & & & & & & & & & & \\
\hline & 0.3943 & 0.0000 & 0.0000 & 1.0000 & & & & & & & & & & & \\
\hline \multirow{2}{*}{ Maturebio } & -0.0326 & 0.0020 & 0.5471 & 0.1252 & & & & & & & & & & & \\
\hline & 0.0000 & 0.7473 & 0.0000 & 0.0000 & 1.0000 & & & & & & & & & & \\
\hline \multirow{2}{*}{ LCAPmature } & 0.0470 & 0.7954 & 0.0499 & 0.6058 & 0.0434 & & & & & & & & & & \\
\hline & 0.0000 & 0.0000 & 0.0000 & 0.0000 & 0.0000 & 1.0000 & & & & & & & & & \\
\hline \multirow{2}{*}{ LCAPmaturebio } & -0.0210 & 0.1212 & 0.7509 & 0.0923 & 0.7369 & 0.1523 & 1.0000 & & & & & & & & \\
\hline & 0.0006 & 0.0000 & 0.0000 & 0.0000 & 0.0000 & 0.0000 & 1.0000 & & & & & & & & \\
\hline SIZE & $\begin{array}{c}-0.0092 \\
0.1347\end{array}$ & $\begin{array}{l}0.0358 \\
0.0000\end{array}$ & $\begin{array}{c}-0.0835 \\
0.0000\end{array}$ & $\begin{array}{l}0.1095 \\
0.0000\end{array}$ & $\begin{array}{c}-0.0572 \\
0.0000\end{array}$ & $\begin{array}{l}0.0682 \\
0.0000\end{array}$ & $\begin{array}{c}-0.0510 \\
0.0000\end{array}$ & 1.0000 & & & & & & & \\
\hline$L E V$ & $\begin{array}{c}-0.1294 \\
0.0000\end{array}$ & $\begin{array}{c}-0.0254 \\
0.0000\end{array}$ & $\begin{array}{c}-0.0549 \\
0.0000\end{array}$ & $\begin{array}{c}-0.0615 \\
0.0000\end{array}$ & $\begin{array}{c}-0.0443 \\
0.0000\end{array}$ & $\begin{array}{c}-0.0412 \\
0.0000\end{array}$ & $\begin{array}{c}-0.0430 \\
0.0000\end{array}$ & $\begin{array}{l}0.1195 \\
0.0000\end{array}$ & 1.0000 & & & & & & \\
\hline \multirow{2}{*}{$R O A$} & 0.3104 & 0.0484 & -0.0108 & 0.0285 & -0.0142 & 0.0472 & -0.0049 & 0.0214 & -0.1075 & 1.0000 & & & & & \\
\hline & 0.0000 & 0.0000 & 0.0801 & 0.0000 & 0.0213 & 0.0000 & 0.4269 & 0.0005 & 0.0000 & & & & & & \\
\hline$R \mathcal{E D}$ program & $\begin{array}{c}-0.0083 \\
0.1761\end{array}$ & $\begin{array}{c}-0.0271 \\
0.0000\end{array}$ & $\begin{array}{c}-0.0037 \\
0.5440\end{array}$ & $\begin{array}{c}-0.0263 \\
0.0000\end{array}$ & $\begin{array}{c}-0.0010 \\
0.8708\end{array}$ & $\begin{array}{c}-0.0207 \\
0.0008\end{array}$ & $\begin{array}{c}-0.0012 \\
0.8410\end{array}$ & $\begin{array}{l}0.0508 \\
0.0000\end{array}$ & $\begin{array}{c}-0.0024 \\
0.6941\end{array}$ & $\begin{array}{l}0.0027 \\
0.6597\end{array}$ & 1.0000 & & & & \\
\hline \multirow{2}{*}{ GROW } & -0.1481 & -0.0869 & -0.0111 & -0.0002 & 0.0024 & -0.0491 & -0.0001 & 0.2078 & 0.0560 & 0.0140 & 0.1349 & & & & \\
\hline & 0.0000 & 0.0000 & 0.0729 & 0.9751 & 0.6920 & 0.0000 & 0.9922 & 0.0000 & 0.0000 & 0.0226 & 0.0000 & 1.0000 & & & \\
\hline \multirow{2}{*}{ OCF } & 0.3161 & -0.0039 & -0.0267 & 0.0093 & -0.0370 & -0.0003 & -0.0189 & 0.0235 & -0.1126 & 0.2578 & 0.0130 & 0.0390 & 1.0000 & & \\
\hline & 0.0000 & 0.5217 & 0.0000 & 0.1301 & 0.0000 & 0.9639 & 0.0021 & 0.0001 & 0.0000 & 0.0000 & 0.0342 & 0.0000 & 1.0000 & & \\
\hline \multirow[t]{2}{*}{ DT } & -0.1753 & -0.0880 & -0.0225 & -0.1226 & -0.0289 & -0.1264 & -0.0303 & -0.0067 & 0.0735 & -0.0242 & 0.0065 & 0.0461 & 0.0381 & & \\
\hline & 0.0000 & 0.0000 & 0.0003 & 0.0000 & 0.0000 & 0.0000 & 0.0000 & 0.2789 & 0.0000 & 0.0001 & 0.2939 & 0.0000 & 0.0000 & 1.0000 & \\
\hline \multirow{2}{*}{$I N V$} & -0.1259 & -0.0743 & -0.0110 & -0.0109 & 0.0067 & -0.0413 & -0.0013 & 0.2392 & 0.1338 & -0.0083 & 0.1326 & 0.7556 & 0.0546 & 0.0251 & 100000 \\
\hline & 0.0000 & 0.0000 & 0.0745 & 0.0777 & 0.2772 & 0.0000 & 0.8291 & 0.0000 & 0.0000 & 0.1761 & 0.0000 & 0.0000 & 0.0000 & 0.0000 & 1.0000 \\
\hline
\end{tabular}

Note. See Table 2 for variable definitions. 


\subsection{Regression Results and Discussion}

For the analysis, panel data is used. Panel data analysis provides a more accurate inference of model parameters and furthermore it pools the data to generate more accurate predictions for individual outcomes and confident results [38]. Table 4 represents the logit regression results for the association between the LCAP (firms having below the median R\&D capitalization) and the Mature (the steady state with respect to a firm's R\&D program). To test Hypothesis 1, the association between the low capitalizer and the steady state with respect to a firm's R\&D program, with the categorization of the dependent variable, a logit regression model is employed for the following reasons: (1) For easier interpretation; (2) To find meaningful comparisons between groups, even in qualitative aspects focusing on tendencies of each group; (3) To remove deficiencies in dealing with outliers that can be usually found in linear regression using unbiased coefficient estimate.

Table 4. Logit regression results.

\begin{tabular}{ccc}
\hline Variables & Expected Sign & Dependent Variable: LCAP \\
\hline Constant & $?$ & $1.2138^{* * *}(3.75)$ \\
Mature & + & $\mathbf{1 . 0 4 2 2}^{* * *}(\mathbf{3 4 . 4 0})$ \\
MatureBio & - & $-\mathbf{0 . 4 1 0 4} 4^{* * *}(-\mathbf{5 . 2 0})$ \\
SIZE & $+/-$ & $0.0185^{*}(1.86)$ \\
LEV & $+/-$ & $-0.5030^{* * *}(-7.06)$ \\
ROA & $+/-$ & $0.7589^{* * *}(6.50)$ \\
RED Program & - & $-13.5627^{* * *}(-29.35)$ \\
GROW & $+/-$ & $-0.0171^{* *}(-2.08)$ \\
Industry dummies & & Included \\
Year dummies & & Included \\
\hline Chi-Square & & 5087.98 \\
$N$ & & 26,333
\end{tabular}

Note. See Table 2 for variable definitions. $t$-values are shown in parentheses. ${ }^{*} p<0.10 .{ }^{* *} p<0.05 .{ }^{* * *} p<0.01$.

The results show that the Mature has a significant positive association with the LCAP, while the Maturebio has a significant negative association $(p<0.01)$, which together provide support for H1. This result implies that when the firm is in the steady state with respect to the firm's R\&D intensity, it is less likely to capitalize R\&D. However, biotech firms seem more likely to capitalize R\&D even in the steady state, as predicted. Capitalization of the R\&D outlay on the Statement of Financial Position instead of expensing on the Income Statement results in an instant increase of profit and market value-boosting. For biotech firms that make a huge investment on $R \& D$, there may be no alternative but to continuously capitalize R\&D expenditures even if uncertainty is somewhat expected, hopefully anticipating future sustainable success.

Significant associations are also seen between LCAP and the control variables. Some of the control variables (SIZE, ROA) show a significant positive association with LCAP, and the others (LEV, R\&D program, GROW) show a significant negative association.

Table 5 represents the regression results for the association between the LCAPmature (firms that are in R\&D mature stage and have below the median R\&D capitalization) and tax avoidance. The results for OLS regression show that LCAPmature has a significant positive association with tax avoidance and LCAPmaturebio a negative association with tax avoidance $(p<0.01)$, both of which provide support for $\mathrm{H} 2$. These results imply that when firms are in an R\&D mature stage and have low (below sample median) R\&D capitalization, they tend to engage in aggressive tax planning by immediately deducting R\&D expenses. However, the results suggest that biotech firms are not likely to engage in tax avoidance activities even in the R\&D steady state. Unlike firms that tend to make $R \& D$ investments in the R\&D mature stage for tax avoidance purposes, biotech firms do not seem to discretionally treat $R \& D$ accounting for tax avoidance purposes even in the R\&D steady state. This is relevant to the results proved in the Hypothesis 1 test. Tax avoidance strategy using R\&D in not in 
the interest of biotech firms, at least until they achieve the success goals they want. Biotech firms only care about future sustainable growth through successful completion of $R \& D$, which may or may not be realized.

Table 5. Regression results.

\begin{tabular}{|c|c|c|c|}
\hline \multirow{2}{*}{ Variables } & \multirow{2}{*}{ Expected Sign } & \multicolumn{2}{|c|}{ Dependent Variable: TAvoid } \\
\hline & & OLS Regression & Clustered Robust (year) \\
\hline Constant & ? & $-0.0532^{* * *}(-2.86)$ & $-0.0532^{*}(-1.98)$ \\
\hline LCAPmature & + & $0.0034 *(1.78)$ & $0.0034(1.60)$ \\
\hline LCAPmatureBio & - & $-0.0263^{* * *}(-3.69)$ & $-0.0263^{* *}(-2.50)$ \\
\hline SIZE & $+/-$ & $0.0028^{* * *}(4.10)$ & $0.0028 *(2.05)$ \\
\hline LEV & - & $-0.0585^{* * *}(-12.35)$ & $-0.0585^{* * * *}(-3.57)$ \\
\hline$R O A$ & $+/-$ & $0.1907^{* * *}(48.29)$ & $0.1907^{*}(1.94)$ \\
\hline$O C F$ & + & $0.4138^{* * *}(43.76)$ & $0.4138^{* * *}(5.72)$ \\
\hline GROW & $+1-$ & $-0.0080^{* * *}(-12.52)$ & $-0.0080^{* *}(-2.17)$ \\
\hline$D T$ & $+1-$ & $-1.8217^{* * *}(-27.77)$ & $-1.8217^{* *}(-2.85)$ \\
\hline$I N V$ & $+1-$ & $-0.0115^{* * *}(-3.97)$ & $-0.0115(-0.70)$ \\
\hline Industry dummies & & Included & Included \\
\hline Year dummies & & Included & Included \\
\hline Fvalue & & $233.31^{* * *}$ & \\
\hline Adjusted $\mathbf{R}^{2}$ & & 0.2457 & 0.2467 \\
\hline$N$ & & 26,334 & 26,334 \\
\hline
\end{tabular}

Note. Panel A. OLS Regression Results. See Table 2 for variable definitions. $t$-values are shown in parentheses. ${ }^{*} p<0.10^{* *} p<0.05^{* * *} p<0.01$.

Significant associations are also seen between tax avoidance and the control variables. Some of the control variables (SIZE, ROA, OCF) have a significant positive association with tax avoidance, and the others (LEV, GROW, DT, INV) show a strong negative association. The Clustered Robust (year) regression results remained consistent with the OLS results for the explanatory variable such as LCAPmaturebio.

\subsection{Robustness Regression}

An analysis is carried out on the regression models using robust regression techniques to eliminate the influence of outlier biases in all specifications. In this analysis, the Mature is coded as 1 if the change in capitalized R\&D outflow is less than the median, and 0 otherwise. As can be seen in Tables 6 and 7 , the results of the study remain consistent when run through the robustness check.

Table 6. Logit Regression Results.

\begin{tabular}{ccc}
\hline Variables & Expected Sign & Dependent Variable: LCAP \\
\hline Constant & $?$ & $1.4751^{* * *}(4.58)$ \\
Mature 2 & + & $\mathbf{0 . 4 5 9 0}$ \\
Mature2Bio & - & $-\mathbf{0 . 2 8 5 . 6 4 )}$ \\
SIZE & $+/-$ & $0.0252^{* * *}(2.57)$ \\
LEV & $+/-$ & $-0.6265^{* * *}(-9.00)$ \\
ROA & $+/-$ & $0.7905^{* * *}(6.86)$ \\
RED Program & - & $-15.6506^{* * *}(-33.05)$ \\
GROW & $+/-$ & $-0.0013(-0.16)$ \\
Industry dummies & & Included \\
Year dummies & & Included \\
\hline Chi-Square & & 4118.95 \\
$N$ & & 26,333 \\
\hline
\end{tabular}

Note. Mature2: coded as 1 if the change in capitalized R\&D outflow is less than the median, 0 otherwise. Mature2Bio: mature2 dummy variable for a biotech firm. See Table 2 for other variables. $t$-values are shown in parentheses. ${ }^{*} p<0.10 .{ }^{* *} p<0.05$. ${ }^{* * *} p<0.01$. 
Table 7. Regression Results.

\begin{tabular}{|c|c|c|c|}
\hline \multirow{2}{*}{ Variables } & \multirow{2}{*}{ Expected Sign } & \multicolumn{2}{|c|}{ Dependent Variable: TAvoid } \\
\hline & & OLS & Clustered Robust (year) \\
\hline Constant & $?$ & $-0.0394^{* *}(-2.14)$ & $-0.0394(-1.67)$ \\
\hline LCAPmature2 & + & $0.0095^{* * *}(5.08)$ & $0.0095^{* * *}(4.14)$ \\
\hline LCAPmature2Bio & - & $-0.0182^{* * *}(-3.09)$ & $-0.0182^{* *}(-2.19)$ \\
\hline SIZE & $+/-$ & $0.0021^{* * *}(3.15)$ & $0.0021^{*}(1.90)$ \\
\hline$L E V$ & - & $-0.0556^{* * *}(-11.87)$ & $-0.0556^{* * *}(-3.59)$ \\
\hline$R O A$ & $+/-$ & $0.1711^{* * *}(40.54)$ & $0.1711(1.69)$ \\
\hline OCF & + & $0.4163^{* * *}(44.34)$ & $0.4163^{* * *}(6.02)$ \\
\hline GROW & $+/-$ & $-0.0078^{* * *}(-12.30)$ & $-0.0078^{*}(-2.58)$ \\
\hline DT & $+1-$ & $-1.8156^{* * *}(-28.10)$ & $-1.8156^{* *}(-2.87)$ \\
\hline$I N V$ & + & $-0.0115^{* * *}(-4.01)$ & $-0.0115(0.69)$ \\
\hline Industry dummies & & Included & Included \\
\hline Year dummies & & Included & Included \\
\hline Fvalue & & $209.70^{* * *}$ & \\
\hline Adjusted $\mathbf{R}^{2}$ & & 0.2264 & 0.2275 \\
\hline$N$ & & 26,334 & 26,334 \\
\hline
\end{tabular}

Note. LCAPMature2: LCAP dummy variable interaction term with Mature2 dummy variable. LCAPMature2Bio: LCAP dummy variable interaction term with Mature2 dummy variable and biotech firm dummy variable. See Table 2 for other variables. $t$-values are shown in parentheses. ${ }^{*} p<0.10 .{ }^{* *} p<0.05 .{ }^{* * *} p<0.01$.

\section{Conclusions}

On the Korean stock market in 2018, the price of biotech stocks skyrocketed in the short term and this has become an issue. R\&D accounting treatment of biotech firms is also a controversial issue. It is doubtful whether $R \& D$ capitalization, an excessively high portion of $R \& D$ spending, is reliable or appropriate, or opportunistic accounting by overly optimistic judgment. Many studies confirm that accounting choices for R\&D capitalization are mostly driven by earnings management motives.

Oswald (2008) finds that firms in an R\&D steady state are less likely to capitalize their R\&D expenditures. Using financial data of the Korean listed firms, this study examined firms' tendencies toward R\&D capitalization and tax avoidance in an R\&D steady state. Similarly, biotech firms were analyzed for tendencies of this nature. According to the overall research results, biotech firms show different tendencies from the firms in other industries.

This study found that firms were less likely to capitalize R\&D expenditures in the R\&D mature stage; however, such a tendency was not found in biotech firms. The results imply that the biotech industry, unlike other industries, tends to maintain a relatively constant level of R\&D capitalization. This tendency may be driven by earnings management motives as treating the R\&D as an intangible asset has a direct impact on an increase of profitability and value. On the other hand, biotech firms may innocently but overoptimistically expect sustainable future benefits through R\&D success. Despite the numerous issues and controversy, recently South Korea's financial authorities have decided to ease R\&D accounting for bio firms, by allowing R\&D capitalization of eligible companies. There has also been an expectation that the guidelines would be strengthened after several supervision cases of biotech firms' R\&D accounting treatment. Financial authorities seem to have decided to take into account the situation of domestic bio-industry, which will potentially lead to growth in line with global standards.

Meanwhile, firms can reduce taxation through immediately deductible R\&D expenses. Therefore, firms with a low tendency to capitalize R\&D and that are in an R\&D steady stage may be prone to aggressive tax planning. Tax avoidance tendencies of biotech firms were also compared. Firms with a low tendency to capitalize $R \& D$ and that are in an $R \& D$ steady stage showed a positive correlation with tax avoidance. Firms may tend to avoid taxes through opportunistic treatment of R\&D accounting. However, biotech firms, even in an R\&D steady state, did not show any tendency of tax avoidance. Biotech firms do not seem to engage in tax avoidance behavior using $R \& D$, unlike other industries. 
Due to uncertainty about future economic benefits from very high $R \& D$ costs, tax avoidance using R\&D accounting treatment seems to be of no interest to biotech firms.

Due to the relatively small number of biotech firms, this analysis may lack in sophistication because of the sample size. Despite such limitations, this paper contributes to the literature by empirically conducting research on R\&D accounting treatment, R\&D state, and tax avoidance behavior, by comparing the tendencies of biotech and non-biotech firms. As South Korea's financial authorities have recently directed new guidelines for biotech firms' R\&D accounting treatment, the specificity of the domestic biotech industry should be considered. Supervisory authorities are taking an attitude to provide timely error correction, rather than post-punishment, in a way that does not limit industry growth potential.

However, the reality is that $30.3 \%$ (281) of the 926 biotech companies have reported almost no sales or zero sales and 373\% (343) of those have not achieved the breakeven point, according to KoreaBIO (Korea Biotechnology Industry Organization). It is said that biotech firms' growth can be high, but their stock prices are overvalued, despite the fact that their fundamentals are relatively low. Hence, policy makers and investors need to be aware of the different tendencies of biotech firms as empirically proved in this study and to learn how to look at the future sustainable growth potential of biotech firms. Particularly, wise judgments of shareholders or potential shareholders are required. In a way, recent issues in biotechnology may be a chance to distinguish between positive and negative activities and choices for the sustainable growth of biotech companies.

Funding: This research received no external funding.

Conflicts of Interest: The author declares no conflict of interest.

\section{References}

1. Tufts, C.S. Post-approval R D raises total drug development costs to $\$ 897$ million. Impact Rep. $2013,5,3$.

2. Cazavan-Jeny, A.; Jeanjean, T.; Joos, P. Accounting choice and future performance: The case of $R \& D$ accounting in France. J. Account. Public Policy 2011, 30, 145-165.

3. Markarian, G.; Pozza, L.; Prencipe, A. Capitalization of R\&D costs and earnings management: Evidence from Italian listed companies. Int. J. Account. 2008, 43, 246-267.

4. Nelson, M.; Elliott, J.; Tarpley, R. How are earnings managed? Examples from auditors. Account. Horiz. 2003. [CrossRef]

5. Oswald, D.R. The determinants and value relevance of the choice of accounting for research and development expenditures in the United Kingdom. J. Bus. Financ. Account. 2008, 35, 1-24. [CrossRef]

6. Armstrong, C.S.; Jennifer, L.B.; David, F.L. The incentives for tax planning. Account. Econ. 2012, 53, $391-411$. [CrossRef]

7. Gupta, S.; Newberry, K. Determinants of the variability on corporate effective tax rates: Evidence from longitudinal data. J. Account. Public Policy 1997, 16, 1-34. [CrossRef]

8. Richardson, G.; Lanis, R. Determinants of Variability in Corporate Effective Tax Rates and Tax Reform: Evidence from Australia. J. Account. Public Policy 2007, 26, 689-704. [CrossRef]

9. Overesch, M.; Wamser, G. Who cares about corporate taxation? Asymmetric tax effects on outbound FDI. World Econ. 2009, 32, 1657-1684. [CrossRef]

10. Stickney, M.; Schreiber, U. RED Intensities, International Profit Shifting, and Investment Decisions; University of Mannheim: Mannheim, Germany, 2008.

11. De Simone, L. Does a common set of accounting standards affect tax-motivated income shifting for multinational firms? J. Account. Econ. 2016, 61, 145-165. [CrossRef]

12. De Simone, L.; Klassen, K.; Seidman, J. Unprofitable affiliates and income shifting behavior. Account. Rev. 2017, 92, 113-136. [CrossRef]

13. Dharmapala, D.; Riedel, N. Earnings shocks and tax-motivated income shifting: Evidence from European multinationals. J. Public Econ. 2013, 97, 95-107. [CrossRef]

14. Markle, K. A comparison of the tax-motivated income shifting of multinationals in territorial and worldwide countries. Contemp. Account. Res. 2016, 33, 7-43. [CrossRef] 
15. Bergin, T.; Drawbaugh, K. How Pfizer has shifted U.S. profits overseas for years. Reuters, 16 November 2015.

16. Jin, Z.; Shang, Y.; Xu, J. The impact of government subsidies on private R\&D and firm performance: Does ownership matter in China's manufacturing industry? Sustainability 2018, 10, 2205. [CrossRef]

17. Lev, B.; Sougiannis, T. The capitalization, amortization, and value-relevance of R\&D. J. Account. Econ. 1996, 21, 107-138.

18. Reynard, E. A method for relating research spending to net profits. Res. Manag. 1979, 22, 12-14. [CrossRef]

19. Xu, J.; Sim, J. Characteristics of Corporate R\&D Investment in Emerging Markets: Evidence from Manufacturing Industry in China and South Korea. Sustainability 2018, 10, 3002. [CrossRef]

20. Aboody, D.; Lev, B. The Value Relevance of Intangibles: The Case of Software Capitalization. J. Account. Res. 1998, 36, 161-191. [CrossRef]

21. Dinh, T.; Kang, H.; Schultze, W. Capitalizing Research \& Development: Signaling or Earnings Management? Eur. Account. Rev. 2016, 25, 373-401.

22. Ballas, A.; Anagnostopoulou, S.C. Tax Incentives as Determinants of Accounting for and Spending on R\&D: An International Analysis. 2014. Available online: https:/ / papers.ssrn.com/sol3/papers.cfm?abstract_id= 2504435 (accessed on 2 October 2014).

23. Givoly, D.; Shi, C. Accounting for Software Development Costs and the Cost of Capital: Evidence from IPO Underpricing in the Software Industry. J. Account. Audit. Financ. 2008, 23, 271-304. [CrossRef]

24. Percy, M. Financial reporting discretion and voluntary disclosure: Corporate research and development expenditure in Australia. Asia Pac. J. Account. Econ. 2000, 7, 1-31. [CrossRef]

25. Shehata, M. Self-Selection Bias and the Economic Consequences of Accounting Regulation: An Application of Two-Stage Switching Regression to SFAS No. 2. Account. Rev. 1991, 66, 768-787.

26. Daley, L.A.; Vigeland, R.L. The Effect of Debt Covenants and Political Costs on the Choice of Accounting Methods: The Case of Accounting for R\&D Costs. J. Account. Econ. 1983, 5, 195-211.

27. Stickney, C.P.; McGee, V.E. Effective corporate tax rates the effect of size, capital intensity, leverage, and other factors. J. Account. Public Policy 1982, 1, 125-152. [CrossRef]

28. Belz, T.; Hagen, D.V.; Steffens, C. R\&D intensity and the effective tax rate: A mega-regression analysis. J. Econ. Surv. 2000, 3, 988-1010.

29. Desai, M.A.; Daharmapala, D. Corporate tax avoidance and high powered incentive. J. Financ. Econ. 2006, 79, 145-179. [CrossRef]

30. Manzon, G., Jr.; Plesko, G. The Relation between Financial and Tax Reporting Measures of Income. Tax Law Rev. 2002, 55, 175-214.

31. Mills, L. Book-Tax Differences and Internal Revenue Service Adjustments. J. Account. Res. 1998, 36, $343-356$. [CrossRef]

32. Mills, L.; Sansing, R. Strategic Tax and Financial Reporting Decisions: Theory and Evidence. Contemp. Account. Res. 2000, 17, 85-106. [CrossRef]

33. Wilson, R. An Examination of Corporate Tax Shelter Participants. Account. Rev. 2009, 84, 969-999. [CrossRef]

34. Hribar, P.; Collins, D. Errors in estimating accruals: Implications for empirical research. J. Account. Res. 2002, 40, 105-134. [CrossRef]

35. Watts, R.L.; Zimmerman, J.L. Positive Accounting Theory; Prentice-Hall: Englewood Cliffs, NJ, USA, 1986.

36. Siegfried, J. Effective average U.S. corporate income tax rate. Natl. Tax J. 1974, 27, 58-79.

37. Chen, S.; Chen, X.; Cheng, Q.; Shevlin, T. Are family firms more tax aggressive than non-family firms? J. Financ. Econ. 2010, 95, 41-61. [CrossRef]

38. Jianu, I.; Jianu, I. The Share Price and Investment: Current Footprints for Future Oil and Gas Industry Performance. Energies 2018, 11, 448. [CrossRef]

(C) 2018 by the author. Licensee MDPI, Basel, Switzerland. This article is an open access article distributed under the terms and conditions of the Creative Commons Attribution (CC BY) license (http:/ / creativecommons.org/licenses/by/4.0/). 